\title{
IDENTIFIKASI KEBUTUHAN PUSAT SUMBER BELAJAR PADA SEKOLAH LANJUTAN PERTAMA DAN SEKOLAH LANJUTAN ATAS DI INDONESIA
}

\author{
Robinson Situmorang
}

\begin{abstract}
This research covering 30 junior High School in 10 regions in Indonesia aims at identifying the needs for learning resource center. the findings show that all schools have performed the funcion of learning resource center in instructional activities and $70 \%$ of the teachers has used media in their instructions; $78 \%$ of the schools have included learning resource center in their school stuctures; but only $30 \%$ of them treat the learning resource centers as formal organizations. more over, 90\% of the schools provide special room for learning resource center which are generally used for Audio Visual. besides, the hardware and software of learning resources are not as complete as they should be. Based on the findings this research recomends the goverment facilitates the schools to develop learning resources center in each school as it has important and strategic roles in improving the quality of instructional process and competencies.
\end{abstract}

Kata kunci: pusat sumber belajar, fungsi pusat sumber belajar, kebutuhan pusat sumber belajar.

\section{PENDAHULUAN}

Latar Belakang Masalah

Perkembangan ilmu pengetahuan dan teknologi telah menciptakan perubahan dalam segala aspek kehidupan, termasuk dalam sektor pendidikan. Sekolah sebagai lembaga terdekat dengan sistem pendidikan, merupakan lembaga yang terkena langsung dengan perubahan tersebut. Oleh karena itu, sudah saatnya sekolah mengantisipasi perubahan tersebut bila tidak ingin tertinggal dengan kemajuan yang sedang terjadi.

Salah satu antisipasi yang patut dipertimbangkan setiap sekolah adalah pengadaan pusat sumber belajar (PSB) sebagai wadah untuk mempelajari semua kemajuan yang terjadi dan sebagai pusat layanan belajar bagi guru dan siswa.

Untuk pengadaan pusat sumber belajar tersebut, tentu saja ada standar minimal yang harus dipenuhi ole h setiap sekolah sehingga keefektifannya sebagai unit pendukung dalam sistem pembelajaran dapat terpenuhi. Oleh karena itu, untuk mendapatkan informasi tentang standar minimal fasilitas PSB yang dimiliki setiap sekolah, perlu kiranya ada serangkaian kegiatan penelusuran ke sekolah-sekolah untuk memetakan sekolah-sekolah yang telah memiliki PSB atau yang telah menjalankan fungsi-fungsi PSB dalam mendukung kegiatan pembelajarannya.

\section{Identifikasi Masalah}

Dari latar belakang masalah di atas dapat diidentifikasi beberapa masalah yang akan menjadi fokus dalam kegiatan ini. Masalah-masalah tersebut adalah sebgai berikut:

1. Berapa banyak guru yang telah menggunakan fasilitas atau fungsi-fungsi PSB dalam kegiatan mengajarnya?

2. Apakah sekolah-sekolah yang memiliki PSB telah memasukkan PSB ke dalam struktur lembaga atau sekolah?

3. Apakah sekolah telah memiliki ruangan belajar yang dilengkapi dengan fasilitas-fasilitas PSB?

4. Apakah sekolah memiliki peralatan (hardware) media yang memadai untuk menunjang kegiatan pembelajarannya?

5. Apakah sekolah telah memiliki program atau software pembelajaran sesuai dengan kebutuhannya?

\section{Tujuan Identifikasi Kebutuhan PSB}

Secara umum tujuan identifikasi kebutuhan PSB ini untuk mendapatkan data lapangan mengenai keberadaan PSB di sekolah-sekolah mulai dari SMP sampai SMA di seluruh Indonesia. Dari informasi tersebut diharapkan dapat diketahui prospek pengembangan PSB ke depan serta kebutuhan tipe PSB bagi masing-masing sekolah. 
Secara khusus tujuan kegiatan ini adalah untuk:

1. mengidentifikasi personel (guru) yang telah menggunakan fasilitas atau fungsi-fungsi PSB dalam kegiatan mengajarnya.

2. mengidentifikasi keberadaan unit PSB dalam struktur lembaga atau sekolah.

3. mengidentifikasi ketersediaan ruangan belajar yang dilengkapi dengan fasilitas-fasilitas PSB.

4. mengidentifikasi peralatan (hardware) media yang telah dimiliki sekolah.

5. mengidentifikasi program-program pembelajaran (software) yang tersedia atau yang telah dimiliki sekolah.

\section{Konsep Pengembangan PSB}

\section{Pengertian Pusat Sumber Belajar}

Secara sederhana pusat sumber belajar (PSB) adalah tempat atau lembaga di mana berbagai sumber belajar diorganisasikan ke dalam sistem pembelajaran guna memenuhi kebutuhan belajar siswa dan kebutuhan mengajar guru. Dengan demikian pusat sumber belajar akan menjadi sistem pendukung dalam pencapaian tujuan atau kompetensi pembelajaran.

Adanya kata diorganisasikan, memberi penegasan bahwa pusat sumber belajar berbeda dengan sumber belajar. Oleh karena itu, tempat kumpulan sumber belajar belum dapat disebut pusat sumber belajar.

Bila kita mengutip pendapat F. Persifal dan $\mathrm{H}$. Elington, pusat sumber belajar adalah tempat atau bagunan yang dirancang secara khusus untuk tujuan menyimpan, merawat, mengembangkan, dan memanfaatkan berbagai sumber belajar, baik untuk kebutuhan belajar secara individual maupun kelompok. Ricard N. Tuker (1979), menyebutnya sebagai media center. Tempat atau departemen yang memberikan fasilitas pendidikan, pelatihan dan pengenalan melalui berbagai media, serta pemberian layanan penunjang pembelajaran, mulai dari sirkulasi peralatan audio-visual, penyajian program-progran video, pembuatan katalog, sampai kepada pemanfaatan sumber-sumber belajar lainnya.

\section{Perkembangan Pusat Sumber Belajar}

Sejarah perkembangan pusat sumber belajar dapat dikatakan sebagai suatu proses yang kontinum dari pengembangan sarana belajar. Mulai dari hanya sekedar penyediaan sumber belajar cetak hingga menjadi penyediaan sarana belajar; mulai dari sekedar alat bantu pengajaran hingga menjadi bagain integral dalam sistem pembelajaran; mulai dari sekedar unit yang membantu proses belajar mengajar hingga pada akhirnya menjadi suatu lembaga yang profesioanal dalam menunjang pencapain tujuan pembelajaran.

Hal ini seperti yang dikemukakan oleh Merril dan Drop (1977), yang menyebut pusat sumber belajar sebagai suatu kegiatan yang terorganisir yang terdiri dari Direktur, staf, peralatan dan bahan-bahan pembelajaran yang ditempatkan dalam satu lokasi serta mempunyai satu atau lebih fasilitas khusus untuk perencanaan, produksi, penyajian, dan pengembangan yang berhubungan dengan kurikulum dan pengajaran pada suatu universitas atau sekolah.

Dari apa yang diuraikan di atas, dapat dikatakan bahwa PSB sebagai bagian integral dalam sistem pembelajaran terus berkembang baik dari segi sarana dan prasarana yang dimilikinya sampai kepada fungsi-fungsinya dalam mencapai tujuan atau kompetensi pembelajaran.

Peterson (1977) misalnya, mengambarkan PSB sebagai lembaga yang terdiri dari: (1) perpustakaan; (2) ruangan belajar non-tradisional; (3) pelayanan audio-visual, perlatan, serta kegiatan produksi media; dan (4) pengembangan sistem instruksional.

Berikut adalah gambaran PSB menurut Petrson (1977).

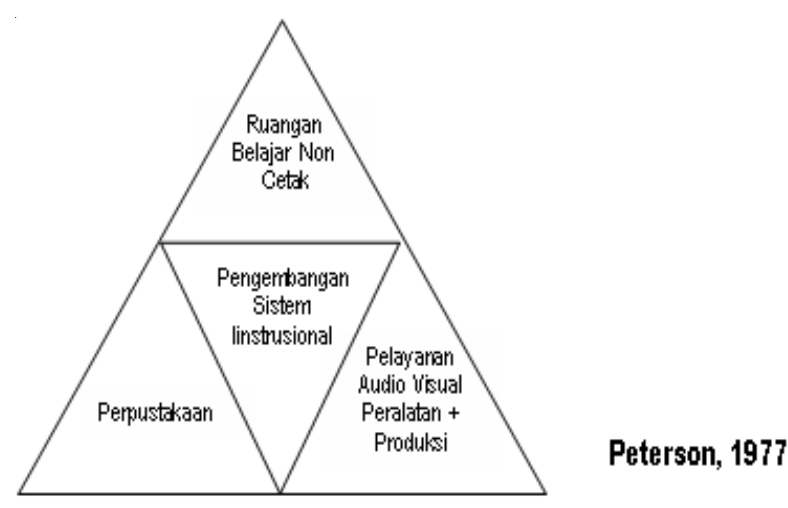

Gambar Komponen PSB

Menurut Peterson (1977), pada mulanya PSB hanya berupa perpustakaan cetak, kemudian berkembang dengan adanya Ruang Belajar Non-Cetak. Pada fase berikutnya (fase ke 3) PSB memiliki bagian Pelayanan Audio Visual, perlatan dan produksi media pembelajan. Terakhir PSB memiliki bagian pengembangan sistem intruksional. Meskipun muncul yang terakhir, bagian pengembangan sistem intruksional menjadi ciri dari PSB yang berkembang dalam menjawab kebutuhan-kebutuhan pembelajaran.

\section{Fungsi-Fungsi PSB}

Secara umum fungsi-fungsi PSB dapat berkembang sesuai dengan kebutuhan lembaga atau 
sekolah. Sebab yang penting dalam penerapannya adalah keefektivan setiap fungsi dalam menunjang pencapaian tujuan atau kompetensi pembelajaran. Namum demikian dalam setiap PSB ada fungsi yang dominan yang menjadi ciri utamanya.

Adapun fungsi-fungsi yang tedapat dalam PSB adalah: (1) Fungsi Pengembangan Sistem Instruksional, (2) Fungsi Pelayanan Media pembelajaran, (3) Fungsi Produksi Media Pembelajaran, (4) Fungsi Pelatihan, dan (5) Fungsi Administrasi.

\section{Fungsi Pengembangan Sistem Instruksional}

Fungsi ini dikatakan yang utama karena aktivitas PSB bermuara dari fungsi ini kemudian menyebar kefungsi-fungsi lainnya. Fungsi pengembangan sistem instruksional membantu para guru, dosen dan fasilitator membuat rancangan pembelajaran untuk meningkatkan efektivitas dan efisiensi proses pembelajaran. Dengan adanya fungsi pengembangan instruksional, maka kebutuhan peyang tidak ada di pasaran dapat terpenuhi

2. Fungsi Pelayanan Media Pembelajaran

Fungsi ini memberikan layanan kepada guru, dosen dan fasilitator terhadap kebutuhan media pembelajaran. Mulai dari memilih media yang tepat, teknik penyajiannya, sampai kepada pemanfaatan berbagai jenis media lainnya. Sedangkan layanan kepada peserta didik berupa layanan belajar individual atau kelompok yang berbasis media, khususnya media pembelajaran audio-visual atau media elektronik lainnya.

3. Fungsi Produksi Media Pembelajaran

Fungsi ini berhubungan dengan pengadaan media pembelajaran yang tidak tersedia dipasaran, sehingga harus diproduksi sesuai dengan kebutuhan kurikulum yang ada.

4. Fungsi Pelatihan

Fungsi ini bertanggung jawab terhadap pengembangan kemampuan SDM, baik tenaga pengajar maupun staf administrasi lainnya. Bagi tenaga pengajar berkaitan dengan peningkatan kompetensi mengajar, khususnya dalam penggunaan media dan sumber-sumber belajar lainnya, sedangakan bagi staf dalam pengeloloaan sumber belajar dan pelayanan yang baik bagi pengguna PSB.

5. Fungsi Administrasi

Fungsi ini bertanggung jawab terhadap pegelolaan layanan, sumber-sumber belajar, dan pengadministrasian fungsi-fungsi lainnya. Dengan demikian sistem layanan kepada pengguna PSB dapat belangsung secara tertib dan lancar.

Seperti dikemukakan sebelumnya, bahwa suatu PSB tidaklah harus memiliki semua fungsi yang ada, namun yang pasti beberapa dari fungsi tersebut. Sebab yang utama bukanlah jumlah fungsinya tetapi keefektivan setiap fungsi dalam mencapai tujuan atau kompetensi pembelajaran.

\section{Peranan PSB dalam Kegiatan Pembelajaran}

Pusat Sumber Belajar (PSB) sebagaimana diuraikan di atas adalah bagian integral dalam sistem pembelajaran. Ini berarti keberadaan suatu PSB sudah menjadi keharusan dalam setiap lembaga (sekolah/ perguruan tinggi), bila ingin mencapai kompetensi yang telah dirumuskan dari setiap mata pelajaran. Sebab tanpa pemberdayaan sumber-sumber belajar yang memadai serta tanpa adanya pegalaman yang konkrit dari setiap mata pelajaran yang dipelajari peserta didik, maka wujud kompetensi dari mata pelajaran tersebut tidak pernah diperoleh secara optimal.

Secara teknis PSB dapat menjadi laboratorium untuk semua mata pelajaran yang ada. Baik itu untuk digunakan langsung oleh siswa maupun melalui perantara guru. Hal ini dimungkinkan, karena PSB dengan fungsi-fungsi yang dimilikinya dirancang untuk memenuhi kebutuhan pembelajaran secara menyeluruh.

Digunakan langsung oleh siswa, artinya siswa dapat belajar secara individual atau kelompok di PSB, melalui program-program media yang dirancang secara khusus untuk mencapai tujuan atau kompetensi dari mata pelajaran tertentu. Sebab di PSB tersedia program-program audio-visual yang dapat menuntun siswa untuk mencapai kompetensi tertentu. Misalnya, untuk percobaan Fisika. Sebelum siswa melakukan percobaan terlebih dahulu ia diminta menonton program video tentang percobaan yang akan dilakukannya. Setelah ia paham tentang apa yang akan dilakukannya, barulah ia melakukan percobaan. Dengan demikian siswa dapat mencapai kompetensi tertentu sesuai dengan kecepatannya dalam belajar.

Melalui perantara guru, artinya guru mempersiapkan segala keperluan pengajarannya di PSB sebelum tampil di depan kelas. Baik itu media yang akan digunakan maupun teknik-teknik penyajiannya. Dengan meningkatnya kualitas pembelajaran yang dilakukannya, akan berdampak kepada hasil belajar siswa. 
Selain itu, PSB dengan fungsi-fungsi yang dimilikinya akan bersinergi dalam meningkatkan kualitas SDM secara menyeluruh, khususnya mereka yang terlibat dalam pengembangan sistem instruksional (guru, dosen, fasilitator, dan pengelola pembelajaran). Dengan meningkatnya kualitas SDM yang ada, berarti meningkat pula kualitas penyelenggaraan pendidikan di setiap lembaga, baik itu sekolah maupun perguruan tinggi.

\section{METODOLOGI PENELITIAN}

\section{Teknik Pengumpulan Data}

Untuk mendapatkan data/informasi yang valid dan dapat dipertanggung jawabkan kebenarannya, teknik pengumpulan data dilakukan dengan menggunakan instrumen berupa, kuesioner dan lembar pengamatan terhadap lima komponen utama PSB, yaitu:

a. Personil yang menggunakan fungsi-fungsi PSB,

b. Kelembagaan PSB dalam struktur organisasi sekola,

c. Ketersediaan ruangan,

d. Ketersediaan peralatan (hardware), dan

e. Ketersediaan program-program pembelajaran (software).

\section{Populasi}

Adapun populasi dari kegiatan identifikasi ini adalah sekolah menengah pertama (SMP) dan sekolah menengah atas (SMA) yang ada di seluruh Indonesia.

\section{Sampel}

Dengan segala keterbatasan yang ada, pengambilan sampel terhadap kegiatan identifkasi keberadaan PSB dilakukan di 10 (sepuluh) wilayah Indonesia, yaitu: lima di Wilayah Pulau Jawa, dan lima di luar Pulau Jawa. Selanjutnya untuk masing-masing wilayah diwakili oleh 3 (tiga) sekolah menengah (boleh SMP atau SMA).

Pemilihan terhadap wilayah penelitian, yaitu Indonesia Barat dan Tengah saja adalah atas kemudahan dalam koordinasi, sebab di wilayahwilayah tersebut terdapat sekolah-sekolah binaan PUSTEKKOM, sedangkan untuk sekolah yang bukan binaan PUSTEKKOM dipilih atas rekomendasi dari dinas pendidikan setempat.

\section{Responden}

Sebagai responden untuk setiap sekolah ditetapkan tujuh orang yang terdiri dari kepala sekolah, koordinator PSB, dan lima orang guru yang menggunakan media dalam kengiatan mengajarnya. Waktu

Adapun waktu kegiatan ini adalah minggu ke empat September 2005, sampai dengan minggu pertama Oktober 2005.

\section{Tempat Penelitian}

Tempat kegiatan meliputi 10 (sepuluh) wilayah, dengan ketentuan 5 (lima) wilayah di dalam Jawa dan 5 (lima) wilaya di luar Jawa, yaitu Sumatera, Kalimantan dan Sulawesi.

Wilayah di dalam Pulau Jawa:
1. Cianjur
2. Bandung
3. Purwokerto
4. Garut
5. Semarang

Wilayah di luar Pulau Jawa:
6. Balik Papan
7. Palu
8. Padang
9. Pakanbaru
10. Mataram

\section{Pengolahan Data}

Data yang telah dikumpulkan akan diolah, baik secara deskriptif kualitatif untuk menentukan Tipe PSB yang dimiliki sekolah.

\section{Petugas Pengumpulan Data/Informasi}

Penanggung Jawab:

1. Kepala Pustekkom Diknas

2. Kepala PSB UNJ

Petugas Untuk Masing-Masing Wilayah:

\begin{tabular}{|c|l|l|l|}
\hline No. & \multicolumn{1}{|c|}{ Wilayah } & \multicolumn{1}{|c|}{ Kota } & \multicolumn{1}{c|}{ Petugas } \\
\hline 1. & Jawa & Semarang & $\begin{array}{l}\text { 1. Budi Prabawani } \\
\text { 2. Sri Hartati }\end{array}$ \\
\hline 2. & Jawa & Cianjur & $\begin{array}{l}\text { 1. Murti } \\
\text { 2. Aristo }\end{array}$ \\
\hline 3. & Jawa & Bandung & $\begin{array}{l}\text { 1. Indro } \\
\text { 2. Sudirman Siahaan }\end{array}$ \\
\hline 4. & Jawa & Garut & $\begin{array}{l}\text { 1. Sunaryo } \\
\text { 2. Nurdin Ibrahim }\end{array}$ \\
\hline 5. & Jawa & Purwokerto & $\begin{array}{l}\text { 1. Dewi Salma Prawiradilaga } \\
\text { 2. Soeharto }\end{array}$ \\
\hline 6. & Luar Jawa & Balik Papan & $\begin{array}{l}\text { 1. Robinson Situmorang } \\
\text { 2. Sudarmono }\end{array}$ \\
\hline 7. & Luar Jawa & Padang & $\begin{array}{l}\text { 1. Ernita } \\
\text { 2. Pustekkom }\end{array}$ \\
\hline 8. & Luar Jawa & Palu & $\begin{array}{l}\text { 1. Bambang Sutjipto } \\
\text { 2. Yatno }\end{array}$ \\
\hline 9. & Luar Jawa & Mataram & $\begin{array}{l}\text { 1. Muchtar M. Noor } \\
\text { 2. Warsoko }\end{array}$ \\
\hline 10. & Luar Jawa & Pakanbaru & $\begin{array}{l}\text { 1. Hirmana } \\
\text { 2. Sismoyowati }\end{array}$ \\
\hline
\end{tabular}




\section{HASIL IDENTIFIKASI}

Hasil identifikasi terhadap keberadaan PSB dikelompokkan menjadi tiga kategori, sebagai berikut:

1. Hasil identifikasi keberadaan PSB untuk masing-masing sekolah dari setiap wilayah. Untuk masing-masing sekolah akan ditampilkan profil keberadaan PSB-nya.

2. Hasil keseluruhan wilayah untuk menggambarkan keberadaan PSB di seluruh Indonesia dan katagori/tipe yang dimilikinya.

Adapun komponen utama PSB meliputi lima komponen yang di distribukan ke dalam indikator, seperti yang terdapat pada tabel berkut ini.

Tabel 1. Komponen Pusat Sumber Belajar

\begin{tabular}{|c|c|c|}
\hline No. & Komponen & Indikator \\
\hline 1. & $\begin{array}{l}\text { Penggunaan fasilitas atau } \\
\text { fungsi-fungsi PSB dalam } \\
\text { kegiatan mengajar guru. }\end{array}$ & $\begin{array}{l}\text { - Jumlah guru di sekolah } \\
\text { - Jumlah guru yang pakai media } \\
\text { - Jekuesi penggunaan media } \\
\text { - Jujis media yang digunakan penggunaan media } \\
\text { - Asal memperoleh media } \\
\text { - Ketergantungan dengan media } \\
\text { - Persepsi terhadap media }\end{array}$ \\
\hline 2. & $\begin{array}{l}\text { Keberadaan PSB dalam } \\
\text { struktur lembaga atau sekolah }\end{array}$ & $\begin{array}{l}\text { - Struktur PSB dalam lembaga } \\
\text { - Tujuan PSB dalam sekolah } \\
\text { - Struktur Organisasi PSB } \\
\text { - Fungsi-fungsi PSB yang di jalankan } \\
\text { - Dana opersional PSB }\end{array}$ \\
\hline 3. & $\begin{array}{l}\text { Ketersedian ruangan belajar } \\
\text { yang dlengkapi fasilitas- } \\
\text { fasilitas PSB. }\end{array}$ & $\begin{array}{l}\text { - Jumlah ruangan yang ada } \\
\text { - Rungsi ruangan } \\
\text { - Ruangan yg dilengkapi media } \\
\text { veadaan ruangan: luas, penerangan, } \\
\text { - Fasilitas dan penataangan: meja, kursih, rak buku, dll. } \\
\text { - Letak ruangan PSB }\end{array}$ \\
\hline 4. & $\begin{array}{l}\text { Peralatan (hardware) media } \\
\text { yang dimiliki sekolah. }\end{array}$ & $\begin{array}{l}\text { - Klasifikasi media } \\
\text { - Jenis, jumlah, dan kualitas media non- } \\
\text { elektronik } \\
\text { - Jenis, jumlah, dan kualitas media elektronik }\end{array}$ \\
\hline 5. & $\begin{array}{l}\text { Program /software } \\
\text { pembelajaran yang tersedia } \\
\text { atau yang dimiliki sekolah. }\end{array}$ & $\begin{array}{l}\text { - Klasifikasi program media } \\
\text { - Media cetak } \\
\text { - Program/software pembelajaran }\end{array}$ \\
\hline
\end{tabular}

\section{Penggunaan fungsi-fungsi PSB oleh guru untuk} kegiatan mengajar

Dari hasil indentifikasi terhadap 30 (tiga puluh) sekolah pada sepulah wilayah di Indonesian terhadap penggunaan fasilitas dan fungsi-fungsi PSB bagi guru untuk menunjang kegiatan mengajarnya diperoleh data sebagai berikut.

Tabel 2. Presentase guru yang telah menggunakan media atau fungsi-fungsi PSB dalam kegiatan mengajarnya

\begin{tabular}{|c|l|l|c|}
\hline No. & \multicolumn{1}{|c|}{ Wilayah } & \multicolumn{1}{|c|}{ Nama Sekolah } & $\begin{array}{l}\text { Prosentase guru yang } \\
\text { telah menggunakan } \\
\text { media atau fungsi- } \\
\text { fungsi PSB dalam ke- } \\
\text { giatan mengajarnya. }\end{array}$ \\
\hline 1. & Semarang & SMP Negeri 1 & 100 \\
\hline & & SMA Negeri 3 & 70 \\
\hline & & SMA Negeri 5 & 80 \\
\hline
\end{tabular}

Tabel 2. Presentase guru yang telah menggunakan media atau fungsi-fungsi PSB dalam kegiatan mengajarnya (lanjutan)

\begin{tabular}{|c|c|c|c|}
\hline No. & Wilayah & Nama Sekolah & $\begin{array}{l}\text { Prosentase guru yang } \\
\text { telah menggunakan } \\
\text { media atau fungsi- } \\
\text { fungsi PSB dalam ke- } \\
\text { giatan mengajarnya. }\end{array}$ \\
\hline \multirow[t]{3}{*}{2.} & Cianjur & SLTP Negeri 2 & 100 \\
\hline & & SLTP Negeri 4 & 100 \\
\hline & & SMA Negeri 1 & 100 \\
\hline \multirow[t]{3}{*}{3.} & Bandung & SMP Negeri 13 & 90 \\
\hline & & SMA Negeri 8 & 50 \\
\hline & & SMU Pasundan 1 & 55 \\
\hline \multirow[t]{3}{*}{4.} & Garut & SMP Negeri 1 & 55 \\
\hline & & SMP Negeri 1 & 100 \\
\hline & & SMA Negeri 2 & 80 \\
\hline \multirow[t]{2}{*}{5.} & Purwokerto & SMP Negeri 1 & 80 \\
\hline & & SMA Negeri 2 & 80 \\
\hline \multirow[t]{3}{*}{6.} & Balik Papan & SMP Negeri 1 & 100 \\
\hline & & SMP Negeri 13 & 95 \\
\hline & & SMA Negeri 1 & 95 \\
\hline \multirow[t]{3}{*}{7.} & Padang & SMA Negeri. 10 Padang & 45 \\
\hline & & SMA Negeri. 1 P. Panjang & 55 \\
\hline & & SMA Negeri. 2 B. Tinggi & 55 \\
\hline \multirow[t]{3}{*}{8.} & Palu & SMP Negeri 1 Palu & 40 \\
\hline & & SMP Negeri.2 Donggala & 15 \\
\hline & & SMA Negeri. Terpadu & 100 \\
\hline \multirow[t]{3}{*}{9.} & Mataram & SMA Negeri 1 Narmada & 70 \\
\hline & & SMP Negeri 1 Gerung & 100 \\
\hline & & SMP Negeri 2 Gunung Sari & 55 \\
\hline \multirow[t]{3}{*}{10.} & Pakanbaru & SMP Negeri 1 Pekan Baru & 30 \\
\hline & & SMA Negeri 2 Dumai & 70 \\
\hline & & SMA Negeri 6 Pekan Baru & 70 \\
\hline
\end{tabular}

2. Keberadaan PSB dalam struktur lembaga atau sekolah

Dari hasil indentifikasi terhadap 30 (tiga puluh) sekolah pada sepulah wilayah di Indonesian terhadap Keberadaan PSB dalam struktur lembaga atau sekolah (sekolah yang sudah memasukkan PSB dalam struktur lembaganya) diperoleh data sebagai berikut.

Tabel 3. Keberadaan PSB dalam struktur lembaga atau sekolah

\begin{tabular}{|l|l|l|c|}
\hline No. & \multicolumn{1}{|c|}{ Wilayah } & \multicolumn{1}{|c|}{ Nama Sekolah } & $\begin{array}{l}\text { Keberadaan PSB dalam } \\
\text { struktur lembaga atau } \\
\text { sekolah }\end{array}$ \\
\hline 1. & Semarang & SMP Negeri 1 & Ada 1 \\
\hline & & SMA Negeri 3 & Ada 1 \\
\hline & & SMA Negeri 5 & Ada 1 \\
\hline & & SMA Negeri 12 & Ada 1 \\
\hline 2. & Cianjur & SLTP Negeri 2 & Ada 1 \\
\hline & & SLTP Negeri 4 & Ada 1 \\
\hline & & SMA Negeri 1 & Ada 2 \\
\hline 3. & Bandung & SMP Negeri 13 & Ada 2 \\
\hline & & SMA Negeri 8 & Ada 1 \\
\hline & & SMU Pasundan 1 & Ada 2 \\
\hline 4. & Garut & SMP Negeri 1 & Ada 2 \\
\hline & & SMP Negeri 1 & Ada 1 \\
\hline & & SMA Negeri 2 & Ada 1 \\
\hline 5. & Purwokerto & SMP Negeri 1 & Ada 2 \\
\hline & & SMA Negeri 2 & Ada 2 \\
\hline 6. & Balik Papan & SMP Negeri 1 & Ada 2 \\
\hline & & SMP Negeri 13 & \\
\hline & & SMA Negeri 1 & \\
\hline
\end{tabular}


Tabel 3. Keberadaan PSB dalam struktur lembaga atau sekolah (lanjutan)

\begin{tabular}{|c|l|l|c|}
\hline No. & \multicolumn{1}{|c|}{ Wilayah } & \multicolumn{1}{|c|}{ Nama Sekolah } & $\begin{array}{c}\text { Keberadaan PSB dalam } \\
\text { struktur lembaga atau } \\
\text { sekolah }\end{array}$ \\
\hline 7. & Padang & SMA Negeri. 10 Padang & - \\
\hline & & SMA Negeri. 1 P. Panjang & - \\
\hline & & SMA Negeri. 2 B. Tinggi & - \\
\hline 8. & Palu & SMP Negeri 1 Palu & Ada 1 \\
\hline & & SMP Negeri.2 Donggala & Ada 1 \\
\hline & & SMA Negeri. Terpadu & - \\
\hline 9. & Mataram & SMA Negeri 1 Narmada & Ada 2 \\
\hline & & SMP Negeri 1 Gerung & Ada 1 \\
\hline & & SMP Negeri 2 Gunung Sari & Ada 1 \\
\hline 10. & Pakanbaru & SMP Negeri 1 Pekan Baru & Ada 1 \\
\hline & & SMA Negeri 2 Dumai & Ada 1 \\
\hline & & SMA Negeri 6 Pekan Baru & Ada 1 \\
\hline
\end{tabular}

Keterangan:

Ada (1) = PSB tercantum dalam strutur sekolah

Ada (2) = PSB tercantum dalam strutur sekolah dan PSB telah dilembagakan

\section{Ketersedian ruangan belajar yang dilengkapi fasilitas-fasilitas PSB}

Dari hasil indentifikasi terhadap 30 (tiga puluh) sekolah pada sepulah wilayah di Indonesian terhadap Ketersedian ruangan belajar (ruang kelas) dari masingmasing sekolah yang dlengkapi fasilitas-fasilitas PSB (media pembelajaran) diperoleh data sebagai berikut.

\section{Tabel 4. Ketersedian ruangan belajar yang dlengkapi fasilitas-fasilitas PSB}

\begin{tabular}{|c|c|c|c|}
\hline No. & Wilayah & Nama Sekolah & $\begin{array}{l}\text { Ketersedian ruang belajar } \\
\text { yang dlengkapi fasilitas- } \\
\text { fasilitas PSB }\end{array}$ \\
\hline \multirow[t]{4}{*}{1.} & Semarang & SMP Negeri 1 & - \\
\hline & & SMA Negeri 3 & M \\
\hline & & SMA Negeri 5 & M \\
\hline & & SMA Negeri 12 & M \\
\hline \multirow[t]{3}{*}{2.} & Cianjur & SLTP Negeri 2 & M \\
\hline & & SLTP Negeri 4 & M \\
\hline & & SMA Negeri 1 & M \\
\hline \multirow[t]{3}{*}{3.} & Bandung & SMP Negeri 13 & - \\
\hline & & SMA Negeri 8 & $\bar{M}$ \\
\hline & & SMU Pasundan 1 & M \\
\hline \multirow[t]{3}{*}{4.} & Garut & SMP Negeri 1 & M \\
\hline & & SMP Negeri 1 & M \\
\hline & & SMA Negeri 2 & SM \\
\hline \multirow[t]{2}{*}{5.} & Purwokerto & SMP Negeri 1 & M \\
\hline & & SMA Negeri 2 & M \\
\hline \multirow[t]{3}{*}{6.} & Balik Papan & SMP Negeri 1 & SM \\
\hline & & SMP Negeri 13 & M \\
\hline & & SMA Negeri 1 & SM \\
\hline \multirow[t]{3}{*}{7.} & Padang & SMA Negeri. 10 Padang & M \\
\hline & & SMA Negeri. 1 P. Panjang & M \\
\hline & & SMA Negeri. 2 B. Tinggi & M \\
\hline \multirow[t]{3}{*}{8.} & Palu & SMP Negeri 1 Palu & M \\
\hline & & SMP Negeri.2 Donggala & M \\
\hline & & SMA Negeri. Terpadu & M \\
\hline \multirow[t]{3}{*}{9.} & Mataram & SMA Negeri 1 Narmada & SM \\
\hline & & SMP Negeri 1 Gerung & M \\
\hline & & SMP Negeri 2 Gunung Sari & - \\
\hline \multirow[t]{3}{*}{10.} & Pakanbaru & SMP Negeri 1 Pekan Baru & SM \\
\hline & & SMA Negeri 2 Dumai & SM \\
\hline & & SMA Negeri 6 Pekan Baru & - \\
\hline
\end{tabular}

Keterangan:

$\mathrm{SM}=$ Sangat memadai (Tersedia lebih dari 5 ruangan yang telah dilegkapi media pembelajaran)

$\mathrm{M}=$ Memadai (Tersedia kurang dari 5 ruangan yang telah dilegkapi media pembelajaran)
4. Peralatan (hardware) media yang dimiliki sekolah.

Dari hasil indentifikasi terhadap 30 (tiga puluh) sekolah pada sepulah wilayah di Indonesian terhadap Peralatan (hardware) media yang dimiliki sekolah (dalam hal ini meliputi semua jenis media) diperoleh data sebagai berikut.

Tabel 5. Peralatan (hardware) media yang dimiliki sekolah

\begin{tabular}{|c|c|c|c|}
\hline No. & Wilayah & Nama Sekolah & $\begin{array}{l}\text { Peralatan (hardware) } \\
\text { media yang dimiliki } \\
\text { sekolah }\end{array}$ \\
\hline \multirow[t]{4}{*}{1.} & Semarang & SMP Negeri 1 & KM \\
\hline & & SMA Negeri 3 & $M$ \\
\hline & & SMA Negeri 5 & $M$ \\
\hline & & SMA Negeri 12 & $M$ \\
\hline \multirow[t]{3}{*}{2.} & Cianjur & SLTP Negeri 2 & $M$ \\
\hline & & SLTP Negeri 4 & $M$ \\
\hline & & SMA Negeri 1 & $M$ \\
\hline \multirow[t]{3}{*}{3.} & Bandung & SMP Negeri 13 & KM \\
\hline & & SMA Negeri 8 & $M$ \\
\hline & & SMU Pasundan 1 & $\mathrm{M}$ \\
\hline \multirow[t]{3}{*}{4.} & Garut & SMP Negeri 1 & KM \\
\hline & & SMP Negeri 1 & $M$ \\
\hline & & SMA Negeri 2 & $M$ \\
\hline \multirow[t]{2}{*}{5.} & Purwokerto & SMP Negeri 1 & $M$ \\
\hline & & SMA Negeri 2 & $M$ \\
\hline \multirow[t]{3}{*}{6.} & Balik Papan & SMP Negeri 1 & SM \\
\hline & & SMP Negeri 13 & $M$ \\
\hline & & SMA Negeri 1 & $M$ \\
\hline \multirow[t]{3}{*}{7.} & Padang & SMA Negeri. 10 Padang & KM \\
\hline & & SMA Negeri. 1 P. Panjang & KM \\
\hline & & SMA Negeri. 2 B. Tinggi & $M$ \\
\hline \multirow[t]{3}{*}{8.} & Palu & SMP Negeri 1 Palu & $\mathrm{M}$ \\
\hline & & SMP Negeri.2 Donggala & KM \\
\hline & & SMA Negeri. Terpadu & $\mathrm{M}$ \\
\hline \multirow[t]{3}{*}{9.} & Mataram & SMA Negeri 1 Narmada & $\mathrm{M}$ \\
\hline & & SMP Negeri 1 Gerung & $\mathrm{M}$ \\
\hline & & SMP Negeri 2 Gunung Sari & KM \\
\hline \multirow[t]{3}{*}{10.} & Pakanbaru & SMP Negeri 1 Pekan Baru & KM \\
\hline & & SMA Negeri 2 Dumai & $M$ \\
\hline & & SMA Negeri 6 Pekan Baru & KM \\
\hline
\end{tabular}

Keterangan:

$\mathrm{SM}=$ Sangat memadai (Tersedia lebih dari 10 jenis media dengan jumlah masing-masing lebih dari 10 unit,

M = Memadai (Tersedia antara 5-9 jenis media dengan jumlah masing-masing antara 5 - 10 unit,

$\mathrm{KM}=$ Kurang Memadai (Tersedia kurang dari 5 jenis media dengan jumlah masing-masing antara 1- 5 unit,

Media = Televisi, VCD, OHP, Taperecorder, Komputer, LCD, Proyektor Slide, Kamera Video, Kamera Foto, Radio dan Media-media sederhana (non-elekronik).

\section{Program /software pembelajaran yang dimiliki} sekolah.

Dari hasil indentifikasi terhadap 30 (tiga puluh) sekolah pada sepuluh wilayah di Indonesian terhadap program / software pembelajaran yang dimiliki sekolah (dalam hal ini meliputi semua jenis media) diperoleh data sebagai berikut. 
Tabel 6. Program/software pembelajaran yang dimiliki sekolah

\begin{tabular}{|c|c|c|c|}
\hline No. & Wilayah & Nama Sekolah & $\begin{array}{l}\text { Program /software } \\
\text { pembelajaran yang } \\
\text { dimiliki sekolah }\end{array}$ \\
\hline \multirow[t]{4}{*}{1.} & Semarang & SMP Negeri 1 & $\mathrm{KM}$ \\
\hline & & SMA Negeri 3 & M \\
\hline & & SMA Negeri 5 & M \\
\hline & & SMA Negeri 12 & M \\
\hline \multirow[t]{3}{*}{2.} & Cianjur & SLTP Negeri 2 & KM \\
\hline & & SLTP Negeri 4 & KM \\
\hline & & SMA Negeri 1 & KM \\
\hline \multirow[t]{3}{*}{3.} & Bandung & SMP Negeri 13 & KM \\
\hline & & SMA Negeri 8 & $M$ \\
\hline & & SMU Pasundan 1 & M \\
\hline \multirow[t]{3}{*}{4.} & Garut & SMP Negeri 1 & KM \\
\hline & & SMP Negeri 1 & M \\
\hline & & SMA Negeri 2 & M \\
\hline \multirow[t]{2}{*}{5.} & Purwokerto & SMP Negeri 1 & M \\
\hline & & SMA Negeri 2 & M \\
\hline \multirow[t]{3}{*}{6.} & Balik Papan & SMP Negeri 1 & SM \\
\hline & & SMP Negeri 13 & $M$ \\
\hline & & SMA Negeri 1 & M \\
\hline \multirow[t]{3}{*}{7.} & Padang & SMA Negeri. 10 Padang & M \\
\hline & & SMA Negeri. 1 P. Panjang & KM \\
\hline & & SMA Negeri. 2 B. Tinggi & $M$ \\
\hline \multirow[t]{3}{*}{8.} & Palu & SMP Negeri 1 Palu & KM \\
\hline & & SMP Negeri.2 Donggala & KM \\
\hline & & SMA Negeri. Terpadu & M \\
\hline \multirow[t]{3}{*}{9.} & Mataram & SMA Negeri 1 Narmada & M \\
\hline & & SMP Negeri 1 Gerung & $\mathrm{M}$ \\
\hline & & SMP Negeri 2 Gunung Sari & KM \\
\hline \multirow[t]{3}{*}{10.} & Pakanbaru & SMP Negeri 1 Pekan Baru & KM \\
\hline & & SMA Negeri 2 Dumai & KM \\
\hline & & SMA Negeri 6 Pekan Baru & KM \\
\hline
\end{tabular}

\section{Keterangan:}

$\mathrm{SM} \quad=$ Sangat memadai (Tersedia lebih dari 10 jenis program dengan jumlah masing-masing lebih dari 10 unit,

M = Memadai (Tersedia antara $5-9$ jenis program dengan jumlah masing-masing antara 5 - 10 unit,

$\mathrm{KM}=$ Kurang Memadai (Tersedia kurang dari 5 jenis program dengan jumlah masing-masing antara 1- 5 unit,

\section{Profil Keberadaa PSB Berdasarkan Lima Indikator dan Tipe yang dimiliki}

Dari hasil indentifikasi terhadap 30 (tiga puluh) sekolah pada sepulah wilayah di Indonesian terhadap 5 (lima) komponen utama yang menjadi indikator keberadaan suatu Pusat Sumber Belajar (PSB) di sekolah, maka berikut ini ditampilkan gambaran tipe PSB yang dimiliki masing-masing sekolah.
Tabel 7. Profil Keberadaan PSB Berdasarkan Lima Indikator dan Tipe yang dimilikinya

\begin{tabular}{|c|c|c|c|c|c|c|c|c|}
\hline \multirow[t]{2}{*}{ No. } & \multirow[t]{2}{*}{ Wilayah } & \multirow[t]{2}{*}{ Nama Sekolah } & \multicolumn{5}{|c|}{$\begin{array}{c}\text { Keberadaan PSB Berdasarkan } \\
\text { Indikator }\end{array}$} & \multirow[t]{2}{*}{$\begin{array}{l}\text { TIPE } \\
\text { PSB }\end{array}$} \\
\hline & & & (1) $\%$ & (2) & (3) & (4) & (5) & \\
\hline \multirow[t]{4}{*}{1.} & \multirow[t]{4}{*}{ Semarang } & SMP Negeri 1 & 100 & Ada 1 & - & KM & KM & $C$ \\
\hline & & SMA Negeri 3 & 70 & Ada 1 & $M$ & $M$ & $M$ & $B$ \\
\hline & & SMA Negeri 5 & 80 & Ada 1 & $M$ & $M$ & $M$ & $B$ \\
\hline & & SMA Negeri 12 & 80 & - & $M$ & $M$ & $M$ & $C$ \\
\hline \multirow[t]{3}{*}{2.} & \multirow[t]{3}{*}{ Cianjur } & SLTP Negeri 2 & 100 & Ada 1 & $M$ & $M$ & KM & C \\
\hline & & SLTP Negeri 4 & 100 & Ada 1 & $M$ & $M$ & KM & $C$ \\
\hline & & SMA Negeri 1 & 100 & Ada 1 & $M$ & $M$ & KM & C \\
\hline \multirow[t]{3}{*}{3.} & \multirow[t]{3}{*}{ Bandung } & SMP Negeri 13 & 90 & Ada 2 & - & KM & KM & $\cdot$ \\
\hline & & SMA Negeri 8 & 50 & Ada 2 & $M$ & $M$ & $M$ & B \\
\hline & & SMU Pasundan 1 & 55 & Ada 1 & $M$ & $M$ & $M$ & $B$ \\
\hline \multirow[t]{3}{*}{4.} & \multirow[t]{3}{*}{ Garut } & SMP Negeri 1 & 55 & Ada 2 & $M$ & KM & KM & $\cdot$ \\
\hline & & SMP Negeri 1 & 100 & Ada 2 & $M$ & $M$ & $M$ & $B$ \\
\hline & & SMA Negeri 2 & 80 & Ada 2 & SM & $M$ & $M$ & $\mathrm{~B}+$ \\
\hline \multirow[t]{2}{*}{5.} & \multirow[t]{2}{*}{ Purwokerto } & SMP Negeri 1 & 80 & Ada 1 & $M$ & $M$ & $M$ & $C$ \\
\hline & & SMA Negeri 2 & 80 & Ada 1 & $M$ & $M$ & $M$ & C \\
\hline \multirow[t]{3}{*}{6.} & \multirow{3}{*}{$\begin{array}{l}\text { Balik } \\
\text { Papan }\end{array}$} & SMP Negeri 1 & 100 & Ada 2 & SM & SM & SM & $A$ \\
\hline & & SMP Negeri 13 & 95 & Ada 2 & $M$ & $\mathrm{M}$ & $\mathrm{M}$ & B \\
\hline & & SMA Negeri 1 & 95 & Ada 2 & SM & $M$ & $M$ & $\mathrm{~B}+$ \\
\hline \multirow[t]{3}{*}{7.} & \multirow[t]{3}{*}{ Padang } & SMA Negeri 10 Pdg. & 45 & - & $M$ & KM & M & $\cdot$ \\
\hline & & SMA Negeri 1 P. Pjg. & 55 & - & $M$ & KM & KM & $\cdot$ \\
\hline & & SMA Negeri 2 B. Tinggi & 55 & - & $M$ & $\mathrm{M}$ & $\mathrm{M}$ & C \\
\hline \multirow[t]{3}{*}{8.} & \multirow[t]{3}{*}{ Palu } & SMP Negeri 1 Palu & 40 & Ada 1 & $M$ & $M$ & KM & C \\
\hline & & SMP Neg. 2 Donggala & 15 & Ada 1 & $M$ & KM & KM & $\cdot$ \\
\hline & & SMA Negeri Terpadu & 100 & $\cdot$ & $M$ & $M$ & $M$ & C \\
\hline \multirow[t]{3}{*}{9.} & \multirow[t]{3}{*}{ Mataram } & SMA Negeri 1 Narmada & 70 & Ada 2 & SM & $M$ & $M$ & B \\
\hline & & SMP Negeri 1 Gerung & 100 & Ada 1 & $M$ & $M$ & $M$ & - \\
\hline & & SMP Negeri 2 G. Sari & 55 & Ada 1 & - & KM & KM & $B$ \\
\hline \multirow[t]{3}{*}{10.} & \multirow[t]{3}{*}{ Pakanbaru } & SMP Negeri 1 P. Baru & 30 & Ada 1 & SM & KM & KM & $\cdot$ \\
\hline & & SMANegeri 2 Dumai & 70 & Ada 1 & SM & $\mathrm{M}$ & KM & $C$ \\
\hline & & SMA Negeri 6 P. Baru & 70 & Ada 1 & SM & KM & KM & 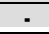 \\
\hline
\end{tabular}

Keterangan:

$1=$ Menjalankan fungsi PSB

2 = Keberadaan PSB dalam struktur sekolah, dan keberadaan struktur PSB

$3=$ Ketersediaan ruangan dan fasilitasnya

$4=$ Ketersediaan hardware (jenis, jumlah, dan kualitasnya)

$5=$ Ketersediaan software (jenis, jumlah, dan kualitasnya)

Ada 1 = PSB tercantum dalam strutur sekolah

Ada 2 = PSB tercantum dalam strutur sekolah dan PSB telah dilembagakan

$\mathrm{SM}=$ Sangat memadai

$\mathrm{M}=$ Memadai

$\mathrm{KM}=$ Kurang memadai

\section{Analisis Data/Pembahasan}

Dari data-data di atas ada beberapa hal yang perlu pembahasan lebih lanjut untuk mendapatkan kejelasan, yaitu:

1) Dari temuan di atas, meski $100 \%$ sekolah sudah menjalankan fungsi PSB, namun baru sekitar $30 \%$ sekolah yang seluruh gurunya $(100 \%)$ telah memanfaatkan fungsi PSB dalam kegiatan mengajarnya. Selanjutnya ada $60 \%$ sekolah yang sebagian besar (70\%) gurunya telah memanfaatkan fungsi PSB dalam kegiatan mengajarnya, dan masih ada sekitar $10 \%$ sekolah 
yang baru sebagian kecil (30\%) gurunya manfaatkan fungsi PSB dalam kegiatan mengajarnya. Hal ini pada umumnya dikarenakan tidak tersedianya media-media yang dibutuhkan di sekolah tersebut.

2) Dari data-data di atas baru $30 \%$ sekolah yang telah memiliki struktur PSB yang dilembagakan, sedangkan $70 \%$ belum mencantumkannya dengan alasan belum tersedianya SDM yang cukup dan tepat untuk melembgakan PSB di sekolahnya. Sedangkan alasan lain berhubungan dengan terbatasnya anggran untuk menjadikan PSB dalam lembaga tersendiri.

3) Terdapat $10 \%$ sekolah yang masih mengalami kesulitan untuk menyediakan ruangan sebagai tempat menjalankan fungsi PSB. Hal ini disebabkan terbatasnya jumlah ruangan yang dimiliki sekolah tersebut. Sehingga peralatan PSB yang telah dimiliki tersebar di beberapa ruang kelas dan ruang administrasi.

4) Masih ada $31 \%$ sekolah yang memiliki hardware kurang memadai dari segi jumlah, jenis dan kualitasnya. Hal ini tentunya akan berdampak kepada rendahnya kualitas pelayanan yang dapat diberikan kepada guru-guru untuk menunjang kegiatan mengajarnya di kelas.

5) Untuk software, terdapat $44 \%$ sekolah memiliki software kurang memadai baik dari segi jumlah, jenis maupun kualitasnya. Ini berarti semakin kecil pula kesempatan siswa memperoleh sumbersumber belajar yang dapat mening-katkan prestasi akademiknya. Sekolah yang software kurang memadai ini pada umumnya adalah sekolah yang lokasinya agak jauh dari dinas pendidikan setempat.

\section{KESIMPULAN DAN PROSPEK PENGEMBANGAN}

\section{Kesimpulan}

Dari 10 (sepuluh) wilayah di seluruh Indonesia dengan masing-masing wilayah diwakili 3 (tiga) sekolah SLTP atau SMA dengan fokus pada 5 komponen PSB diperoleh kesimpulan sebagai berikut:

a. Penggunaan fasilitas atau fungsi-fungsi PSB dalam kegiatan mengajar guru.

a. $100 \%$ sekolah telah menggunakan fasilitas dan menjalankan fungsi PSB dalam pembelajarannya. b. $70 \%$ sguru telah menggunakan media dalam kegiatan mengajarnya

2. Keberadaan PSB dalam struktur/lembaga sekolah.
a. $78 \%$ sekolah yang telah mencantumkan PSB dalam struktur sekolah atau lembaganya.
b. $30 \%$ sekolah telah memiliki struktur sekolah yang dilembagakan.

3. Ketersediaan ruangan yang dilengkapi fasilitasfasilitas PSB.
a. $90 \%$ sekolah telah memiliki ruangan yang difungsikan sebagai ruangan PSB atau ruang media.
b. $25 \%$ seklalh telah memiliki ruangan yang sangat memadai sebagai ruangan PSB atau ruang media.

4. Peralatan (hardware) media yang dimiliki sekolah.
a. $100 \%$ sekolah telah memiliki hardware media pembelajaran.
b. $3 \%$ sekolah telah memiliki hardware media pembelajaran sangat memadai, baik dari jenis, jumlah dan kualitasnya.
c. $66 \%$ sekolah telah memiliki hardware media pembelajaran memadai, baik dari jenis, jumlah dan kualitasnya.
d. $31 \%$ sekolah telah memiliki hardware media pembelajaran kurang memadai, baik dari jenis, jumlah dan kualitasnya.

5. Program (software) pembelajaran yang dimiliki sekolah.
a. $100 \%$ sekolah telah memiliki software media pembelajaran
b. $3 \%$ sekolah telah memiliki software media pembelajaran sangat memada, baik dari jenis, jumlah dan kualitasnya.
c. $53 \%$ sekolah telah memiliki software media pembelajaran memadai, baik dari jenis, jumlah dan kualitasnya.
d. $44 \%$ sekolah telah memiliki software media, baik dari jenis, jumlah dan kualitasnya.

\section{Prospek Pengembangan PSB di Sekolah}

Seperti yang telah diuraikan sebelumnya, "suka atau tidak", bila kita ingin mencapai tujuan atau kompetensi belajar dengan baik; maka seharusnya setiap sekolah PSB atau paling tidak menjalankan fungsi-fungsi PSB sebagai bagian integral dalam sistem pebelajarannya.

Dari temuan di lapangan (hasil identifikasi keberadaan PSB di SLTP dan SMA pada sepuluh wilayah di Indonesia oleh PUSTEKKOM-DIKNAS tahun 2005) 
sesungguhnya, sudah banyak sekolah yang telah menjalankan fungsi-fungsi PSB dalam penyelenggaraan pembelajarannya, meskipun belum memiliki PSB secara kelembagaan. Ini artinya sebagian besar mereka telah menyadari betapa pentingnya peranan sumber belajar dalam pencapaian tujuan atau kompetensi belajar.

Dari temuan-temuan di atas, prospek pengembangan PSB di setiap sekolah (khususnya SLTP dan SMA), sangat optimis. Hanya saja masih perlu ada sosialisasi secara terus menerus terhadap fungsi-fungsi PSB yang lain, sehingga keberadaannya ke depan bisa di lembagakan menjadi PSB yang memiliki struktur dan fungsi-fungsi yang seharusnya dimiliki oleh setiap PSB. Fungsi tersebut meliputi fungsi: Pengembangan Sistem Instruksional, Pelayanan Media Pembelajaran, Produksi, Pelatihan, dan Administrasi.

\section{DAFTAR PUSTAKA}

Anderson, L. W., \& Krathwohl, D. R., (Editor). (2001) A Taxonomy for learning, leaching, and assessing: A revision of Bloom's taxonomy of educational objectives. New York: Addison Weslay Longman, Inc.

Anderson, R. H. (1987). Pemilihan dan pengembangan media untuk pembelajaran. Yusufhadi Miarso, dkk (penerjemah). Jakarta: PAU-UT.

Association for Educational Communications and Technology. (1977). Defenition and glossary of term, Vol. 1. New York: AECT.
Barbara, S. B. \& Rita, R. C. (1994). Teknologi Pembelajaran. Yusufhadi Miarso, dkk (penerjemah). Jakarta: UNJ., dkk

Bloom, B. S. (1956). Taxonomy of education objectives. handbook I: Cognitive domain. New York: Longman, Inc.

Dick, W. \& Carey, L. (1990). The systematic design of instruction $\left(3^{\text {rd }}\right)$. Glenview, Illinois: Scoot, Foresman and Company.

Dryden, G. \& Vos, J. (1999). The learning revolution. New Zealand: The Learning Web.

Filbeck, R. (1974). System in teaching and learning. Lincoln, Nabraska: Professional Educator Publication.

Gerlach, V. S. \& Ely, D. P. (1978). Teaching and media: a systematic approach. Englewood Cliffs, New Jersey: Prentice-Hall.

Heinch, R., Molenda, M. \& Russell, James D. (1995). Instructional media. New York: Macmillan Publishing Company.

Padmo, D. (Editor). (2003). Teknologi pembelajaran. Jakarta: PAU-UT.

Sadiman, A., et. al. (1990). Media pendidikan. Jakarta: CV. Rajawali.

\section{KETERANGAN PENULIS}

Drs. Robinson Situmorang, M.Pd. menjadi dosen tetap S1 Teknologi Pendidikan FIP UNJ. Pernah menulis buku berjudul Desain Pembelajaran bersama dengan Atwi Suparman. Selain sebagai dosen, juga merupakan praktisi di bidang pendidikan dan latihan di dalam maupun di luar lingkungan UNJ. 